\title{
How Does the Presence of Livestock Influence Landscape Preferences? An Image-Based Approach
}

\begin{abstract}
The European Landscape Convention (ELC) emphasises that the public should be extensively involved in the processes of landscape protection, planning and management. In spite of the emerging interest in the relationship between animals and landscapes in the study of animal geography, little is known about the influence of the landscape-animal component on public aspirations and the values attributed to landscape. We conducted a survey in the form of an image-based questionnaire in order to evaluate the influence of certain animal species, in this case livestock, on landscape preferences. The results show that all grazing animals have a positive impact on landscape preferences, although some species seem more popular than others. The preference for scenes with animals decreases, however, when compared with scenes with other landscape features (vegetation, traditional buildings or water). Significant differences in preferences for scenes with animals were observed according to certain sociodemographic variables such as gender, familiarity with the landscape and direct involvement in livestock farming. Of the groups surveyed, livestock farmers showed the strongest preferences for the scenes with animals. The findings of this study can be applied within the citizen participation policies encouraged by the ELC, as well as in the protection, management and planning of rural landscapes in which livestock is an appreciable feature.
\end{abstract}

\section{Keywords:}

Landscape preferences, Animal geography, Livestock, Rural landscapes, European Landscape Convention

\author{
José L. Serrano-Montes ${ }^{1 *}$, Emilio \\ Martínez-lbarra², Jonatan Arias- \\ García ${ }^{2}$ \\ ${ }^{1)}$ Department of Human Geography, \\ Faculty of Arts and Humanities, \\ University of Granada, Spain

\section{2) Department of Regional Geographical Analysis and Physical Geography, Faculty of Arts and Humanities, University of Granada, Spain}

\footnotetext{
*Corresponding author: José L. Serrano-Montes, Department of Human Geography, Faculty of Arts and Humanities, University of Granada, Campus de Cartuja s/n., 18071 - Granada, Spain. Email: joselsm@ugr.es
} 


\section{Introduction}

Animal geography first appeared in the 1990s as a branch of cultural geography that centred on "the study of where, when, why and how nonhuman animals intersect with human societies" (Urbanik 2012, p. 38). Since then this subdiscipline has been growing continually and diversifying (Lorimer \& Srinivasan 2013), giving rise to a wide body of research that analyses the relations between human beings and animals from different geographic perspectives, as manifested in reviews of the literature carried out by authors such as Buller $(2013,2015,2016)$ and Hovorka (2017, 2018a, 2018b).

Ever since this geographic field of research first appeared, various researchers have underlined the role of different animal species in the creation of places and landscapes (Wolch 2002; Wolch et al. 2003). Evans and Yarwood (1995) conducted a pioneering study in the analysis of the relationship between animals and the landscape. In an analysis of the distribution of cattle breeds in the British Isles, they argued that livestock played an important role in the creation of landscape coherences. They claimed that livestock was a significant cultural aspect of the landscape and that the variations in the type of breeds played an important, albeit undervalued, part thereof.

Almost two decades later, Urbanik (2012) explored the cultural landscape resulting from the relationship between humans and different types of animals: pets, working animals, farm animals and wild fauna. This author referred to the importance of our "encounters" with the different species as a key phenomenon in the configuration of cultural landscapes: "(...) the cultural landscape is the built environment - all the things that humans create from a small scale to a large scale. When we apply this concept to pets and the role of animals in culture, we want to think about where and how we encounter animal others and through which cultural mediums" (p. 61).

The increasing interest in the study of the relationship between animals and landscape led to the publication in 2013 of a special issue of the
Landscape Research Journal entitled "Animal and Landscape" (Volume 38, Number 4). This included many new research contributions including the paper by Peltola et al. (2013), who studied how the increasing intrusions by brown bears (Ursus arctos) in search of food in human refuse in a residential area on the edge of a city in Finland was contributing to the creation of a landscape. The increase in the number of encounters and the social reactions to this change in the behaviour of this species, together with the media attention it is receiving, are becoming determining factors in the social construction of the landscape. For his part, Jones (2013) analysed the role of animals in the creation of affective or emotional registers in British rural landscapes. This author shows how the presence of animals and the links that human beings establish with them become key features of individual and collective practices in the rural world, so contributing to the formation of identities in the landscape.

Other interesting research was performed by Sellick \& Yarwood (2013). Situated halfway between rural geography and animal geography, their article reviewed the research so far conducted into livestock and landscape. These authors identified a body of literature, developed above all since the mid-1990s, which "attempts to make sense of the ways in which livestock have been shaped by human culture, aesthetics, sciences, technologies and the very real implications of these interpretations on landscape" (p. 415).

This special issue on animals and the landscape was completed with three papers which analysed the function of extensive livestock in the conservation of the landscape, from an ecological perspective, in three quite different areas: The Greater Caucasus (Neudert et al. 2013), Western Lesvos (Greece) (Kizos et al. 2013) and the island of Hiddensee (Germany) (Pietzsch et al. 2013).

Spanish geographers have also produced some interesting recent research, albeit from a different perspective, in which they analyse the role played by animals in the multisensorial perception of the landscape (Arias-García et al. 2016; Serrano-Montes \& Gómez-Zotano 2017). These studies highlight the importance of animals, both wild and domestic, in 
the perception of wetland and coastal landscapes, emphasizing the importance of the sounds they make.

In the English-speaking world, other important contributions to this field include the paper by Gorman (2017), who analysed the role of farm animals in the creation of "therapeutic landscapes" through social agriculture projects. This study shows that the "non-human presence actively creates and facilitates a therapeutic engagement with place" ( $p$. 315), which is undoubtedly manifested in landscape.

Although the papers cited above highlight a growing interest in recent years in the role of animals in the many dimensions of landscape, there are few recent publications analysing the influence of the different species on landscape preferences. In spite of this, Roe (2013) argued that "the presence of species may have significant impact on the way landscapes are valued regardless of the ecological condition" ( $p$. 402).

According to the guidelines set out in recent international initiatives, such as the European Landscape Convention (ELC) (Council of Europe 2000) or the Latin American Landscape Initiative (IFLA 2013), the study of landscape preferences has become an essential tool for implementing public participation in the processes of landscape protection, planning and management (Barroso et al. 2012; Ode et al. 2010; Sevenant \& Antrop 2010). As a result, a large body of scientific literature on the analysis of landscape perception and preferences has been developed over the last three decades (Buijs et al. 2006; Jorgensen 2011; Kaplan \& Kaplan 1989; Soliva et al. 2010).

Different investigations have highlighted the important role played by sociocultural variables, such as age, place of residence, interest, education, familiarity with the landscape, etc., in landscape preferences (Múgica \& De Lucio 1996; Van den Berg \& Koole 2006; Yang \& Kaplan 1990), while other authors have analysed the influence of natural elements -such as water, vegetation and topography- and cultural attributes, on landscape preferences (Arnberger \& Eder 2011; Arriaza et al. 2004; Gómez-Limón \& de Lucío Fernández 1999).
However, studies analysing the impact of the presence of domestic and wild animals on landscape preferences are still scarce (Roe 2013), to the extent that some researchers seem to have deliberately avoided the inclusion of the animal component in their methodological procedures for the analysis of landscape preferences (Hagerhall 2000; Mealey \& Theis 1995; Sullivan 1994; Tveit 2009).

According to Jacobs (2009), non-human animals can "evoke strong positive or negative emotions in humans, although there is great variance in the quality and strength of the accompanying feelings" (p. 2). Some researchers demonstrated that wildlife plays an important role in emotional attachment to places and landscapes (Folmer etal. 2013). Pioneering studies in the field of landscape preferences, such as Hull \& McCarthy (1988), Benayas et al. (1989) and Benayas (1992), also demonstrated the significant influence of the presence of both wild fauna and domestic animals in a landscape scene.

Lange \& Bishop (2005) highlighted the need to include animals in the analysis of landscape given that they are an important factor in visual perception and scene quality. In view of the specific, sometimes controversial importance of animals in the formulation of landscape quality objectives (Serrano-Montes 2017), it is essential for them to be considered within the framework of the democratic planning of landscape stipulated in international treaties such as the ELC. The analysis of the impact of animals on landscape preferences is especially important for a better understanding of the public aspirations and the values attributed to landscape.

In this paper, we aim to fill this gap by analysing the impact that different animal species may have on landscape preferences. We will be focusing on the influence of domestic livestock on landscape preferences, because, unlike wild animals, livestock are a part of human society whose distribution and presence in rural landscapes is closely subject to decisions of a socioeconomic and political nature. To do so, we conducted a survey using an image-based questionnaire with pairs of pictures whose objective was to evaluate the role of animals on their own and in comparison with other elements in the landscape 
(such as water, a greater density and diversity of vegetation cover and a traditional farmhouse). The methodology was applied to a dehesa landscape in southern Spain.

\section{Methodology}

\subsection{Study Area}

The study area (Figure 1) was the Sierra de Cardeña y Montoro Natural Park (established by Act 2/89 of 18th July 1989 by which the Inventory of Protected Natural Areas in Andalusia was passed and additional measures for its protection were introduced), in Sierra Morena, a mountain range in the northeast of the province of Cordoba (Andalusia, Spain).

From a geological point of view, the study area is mainly located in Los Pedroches batholith, formed by granitic materials from the Peleozoic Era. The average altitude is about 750 meters and the topography is flat like an elevated peneplain (Garzón-García 2005). The study area has a Mediterranean climate with an average annual temperature of $15.8^{\circ} \mathrm{C}$ and an average annual rainfall of $753 \mathrm{~mm}$. The predominant soils, according to the FAO classification, are Cambisols, Regosols and Leptosols (Carbonero \& Fernández-Rebollo 2014).

The vegetation in this area consists of a tree stratum dominated by holm oaks (Quercus ilex), although there are also large numbers of gall oaks (Quercus faginea), cork oaks (Quercus suber) and Pyrenean oaks (Quercus pyrenaica) (Sánchez-Almendro et al. 2011). Under the oaks, annual species of grass flourish producing excellent grazing land. This landscape is known as "dehesa" and was formed out of thinned out Mediterranean forest. The dehesa (or montado in Portugal) is an agro-silvo-pastoral system that extends across the west and south-west of Spain and southern Portugal and is characterized above all by the presence of scattered trees or groups of trees associated with pastures and agricultural areas (Paniza Cabrera 2015).

In terms of wildlife, this area was declared a Special Protection Area (SPA) for birds in 2002 and has since become a habitat for many threatened species in the Iberian Peninsula, including the Spanish imperial
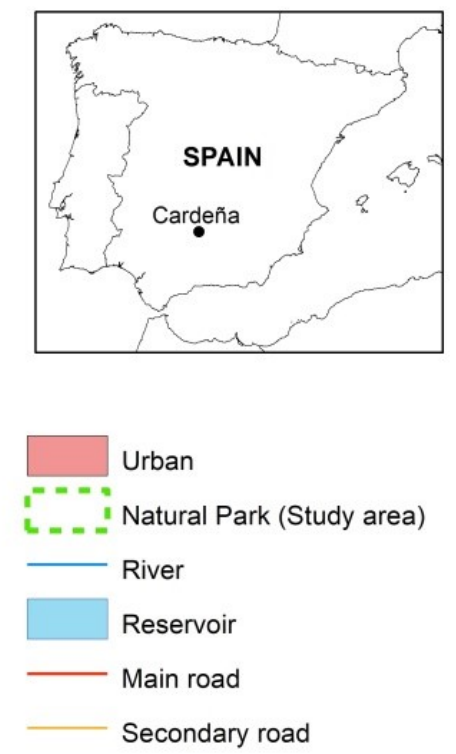

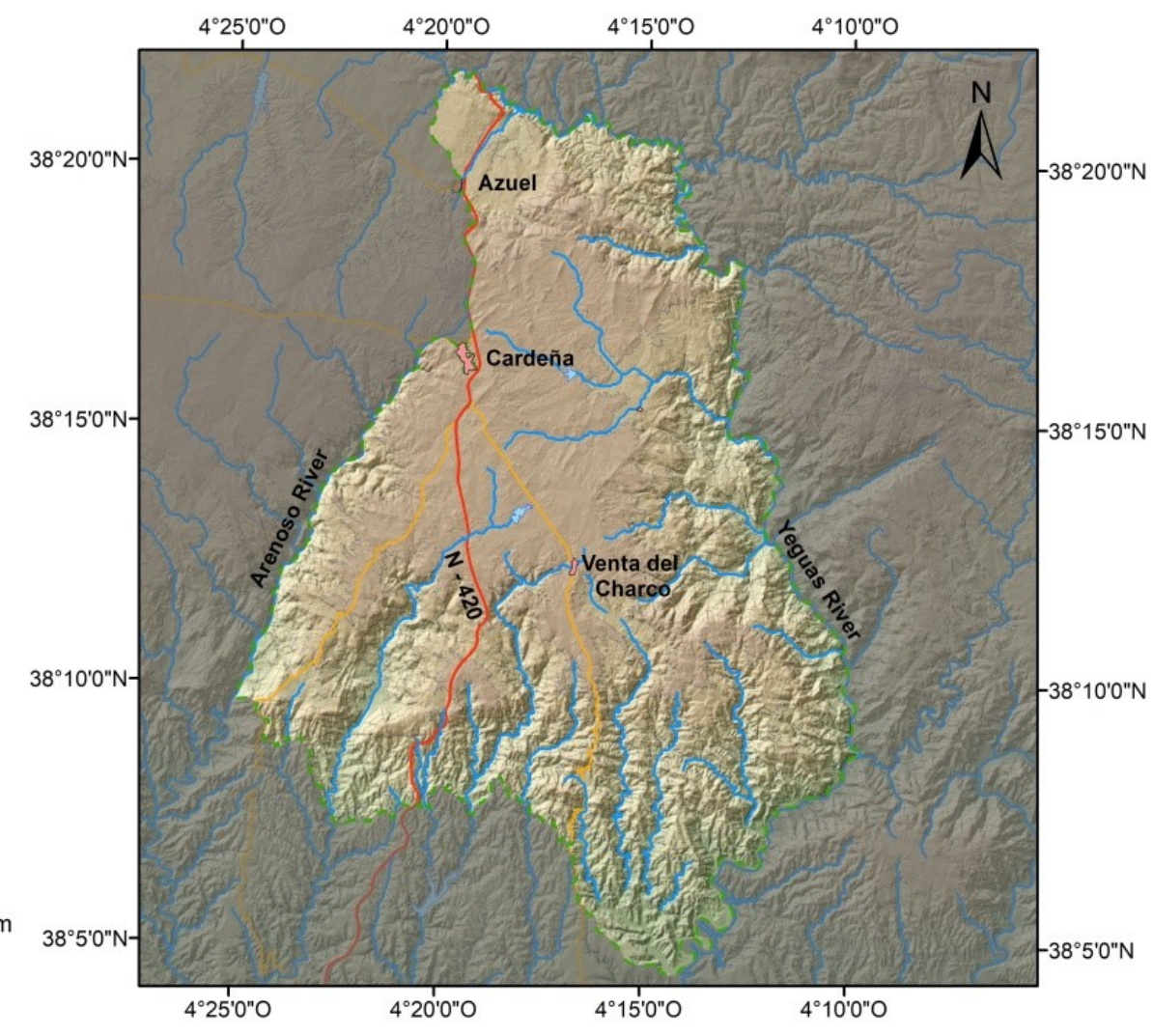

Figure 1: Map of Sierra de Cardeña y Montoro Natural Park. 
eagle (Aquila adalberti) and the wolf (Canis lupus). It is also home to Spain's largest population of Iberian lynx (Lynx pardinus) (Fernández 2011; Quero Fernández de Molina 2007).

Livestock farming and hunting are some of the main human uses of the dehesa landscape and both activities entail the building of dry stone walls and fences restricting human access to the landscape. According to the last livestock census (2009), pigs represent the largest livestock category in the study area $(35,468$ head), followed by sheep $(26,439$ head) and cattle (18,378 head). Although fewer in number, goats (1,739 head) and horses (808 head) are also part of the livestock population of this protected area. Agriculture is less important due to the poor fertility of the soils. Most of the agricultural land is occupied by olive groves -especially in the southern part of the study area-, followed by a small area of cereal fields (Garzón-García 2005; Quero Fernández de Molina 2007). The only municipality within the study area is Cardeña, which, according to the municipal census for 2018 , has a total population of 1,503 inhabitants. The population is made up of 744 men and 759 women with a median age of 48.2 years. The municipal area is made up of the main village centre and two small, outlying hamlets, "Azuel" and "Venta del Charco".

\subsection{Survey Instrument}

We created an image-based questionnaire with 9 pairs of landscape pictures as a survey instrument for analysing the influence of animals on landscape preferences. The use of pictures as representations of real landscapes has been widely tested in studies of landscape perception and preferences (see for example Arnberger \& Eder 2011; Gómez-Limón \& De Lucío Fernández 1999; Soliva et al. 2010). Stamps (1990) found a strong correlation between the preferences observed in situ and those determined using pictures. The validity of this method has been confirmed by various different authors in recent decades (Kaplan \& Kaplan 1989; Law \& Zube 1983; Stewart et al. 1984).

The pictures used in this article were taken in the study area on a clear day in May 2016. The pictures showed dehesa landscape scenes with different attributes: water, denser vegetation, croplands, traditional farmhouses, livestock walls and fences, different farm animal species, etc. In some cases, we had to ask for special authorization to enter private land, and throughout enjoyed the assistance of two forest rangers.

We took a total of 300 pictures from which a preliminary selection was made by 6 experts in landscape from the Department of Regional Geographical Analysis and Physical Geography of the University of Granada. These experts selected a set of pictures containing grazing animals (Iberian pigs, cattle and horses) and another group of images showing the same or similar scenes, but without animals (Hull \& McCarthy 1988). The selection was completed with Spanish dehesa landscape scenes containing bodies of water, a higher density and diversity of vegetation and traditional farmhouses. In order to prevent the choices of the respondents being affected by possible variations in the type of landscape, all the pictures were of the dehesa landscape. It was relatively easy to maintain the same atmospheric conditions in all the pictures, as they were all taken on the same day.

In the composition of each pair of photographs, we took great care to ensure the same levels of brightness, distance and the presence or absence of foregrounds or backgrounds (García Pérez 2002). The final composition with the definitive selection of photographs and the order of the different pairs was decided after testing a provisional photoquestionnaire on 60 people, whom we interviewed on campus at the University of Granada.

In the end, the image-based questionnaire consisted of 5 pairs of landscape pictures in which different scenes with animals were compared with scenes showing other kinds of landscape attributes (see Table 1 and Figure 2). Of the five pairs of pictures that made up the questionnaire, two of them showed a similar scene with and without animals (pairs $A$ and $D$ ). In the other three pairs, the scene with animals was compared with another scene with a striking landscape attribute: a small lake (B), a traditional farmhouse in good condition (C) and a Spanish dehesa landscape with greater density and diversity of vegetation (E). The images used in the final comparison set were all representative of the main attributes that make up the landscape of the study area. 
Four pairs without animals in any of the photographs were also included amongst the pairs of pictures described above so as to prevent respondents from discovering the purpose of the questionnaire. The pictures were printed in colour on high quality $A 3$ paper. The two photographs in each pair were printed on the same page.

The questionnaire was completed with a section asking for information about the respondent (gender, age, education level and job) in order to identify possible sociodemographic factors that might influence landscape preferences.
Table 1: Composition of the five pairs in the image-based questionnaire that were used to compare landscape attributes.

\begin{tabular}{|c|c|c|}
\hline Pair & Scene with animals & Scene without animals \\
\hline A & Cattle & $\begin{array}{l}\text { Similar scene without } \\
\text { cattle }\end{array}$ \\
\hline B & Horses & Water \\
\hline C & Cattle & Traditional farmhouse \\
\hline D & Pigs & $\begin{array}{l}\text { Similar scene without } \\
\text { pigs }\end{array}$ \\
\hline $\mathbf{E}$ & Cattle & $\begin{array}{c}\text { Density and diversity of } \\
\text { vegetation }\end{array}$ \\
\hline
\end{tabular}
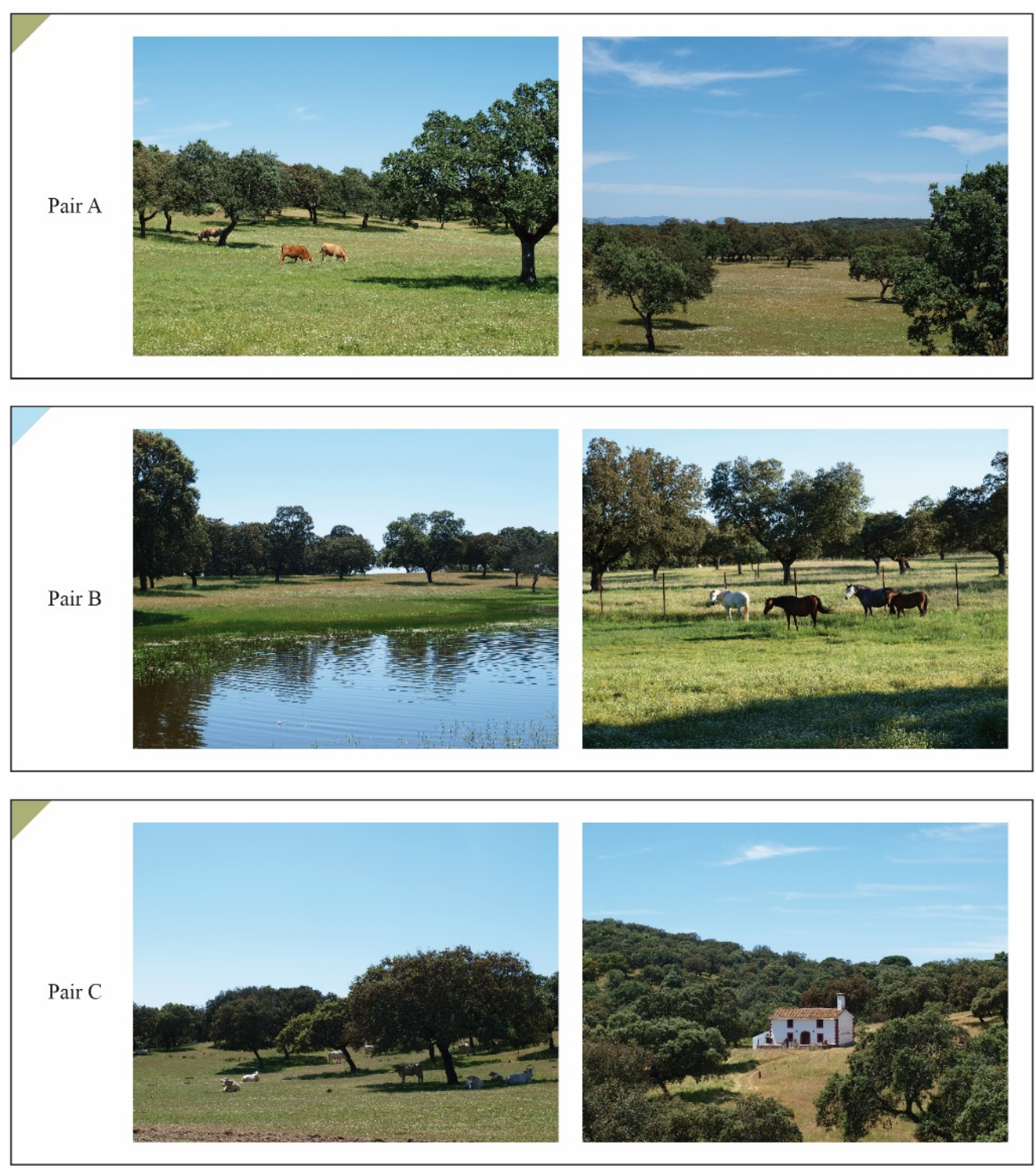

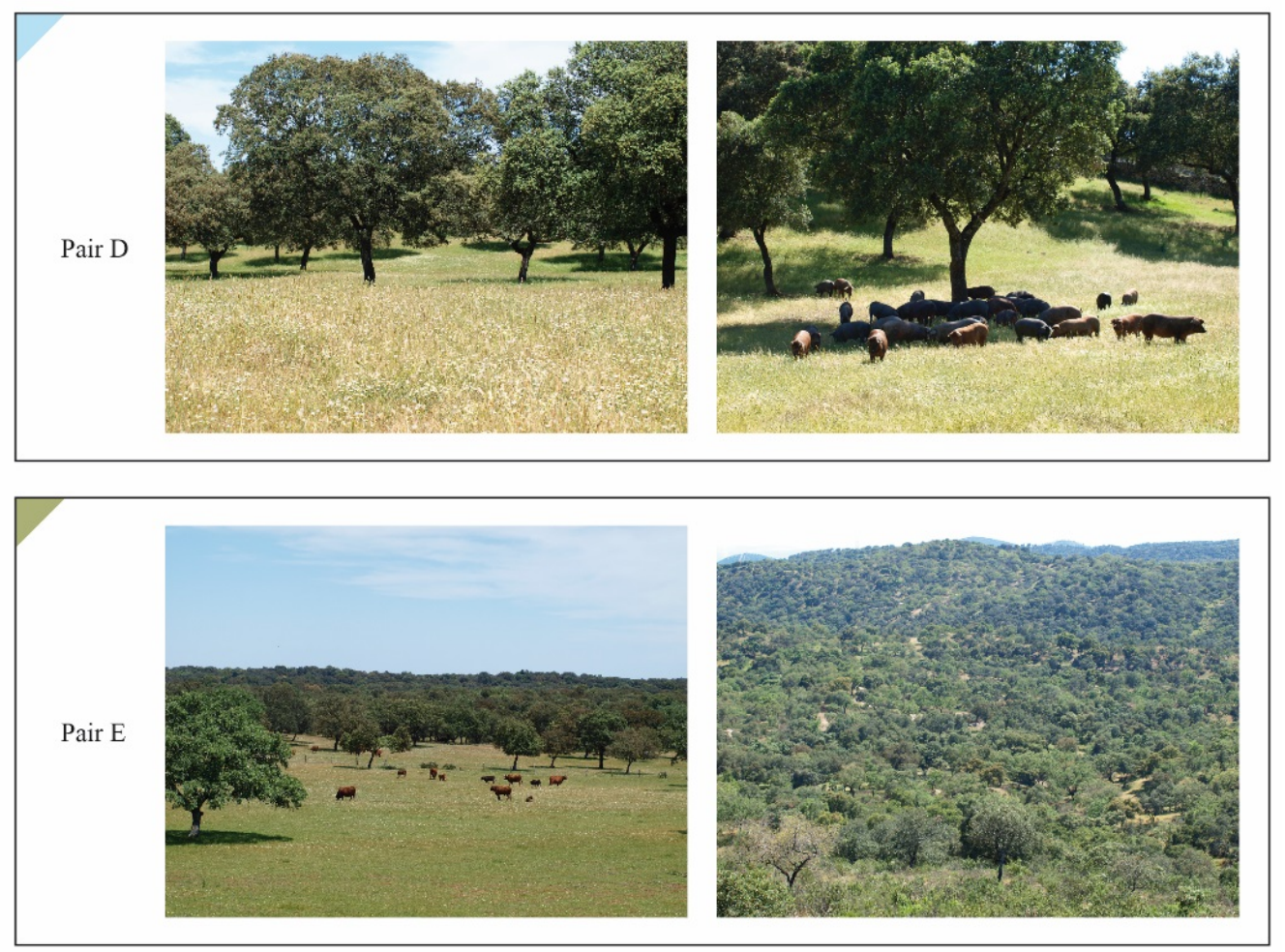

Figure 2: Pairs of pictures of landscape used in the questionnaire.

\subsection{Data Collection}

The data were collected from a survey conducted during work days and weekends in September, October and November 2016 using the image-based questionnaire described above. The questionnaire was presented to each respondent individually. They were told to choose their favourite image from each pair in the album. As stated by Howley et al. (2012), the respondents were instructed to appraise the beauty of the landscape rather than the quality of the photograph (framing, brightness, etc.).

In order to evaluate the possible influence of factors such as familiarity with the landscape or place of residence (Múgica \& De Lucio 1996; Van den Berg \& Koole 2006; Yu 1995), the survey was conducted in two different places: Cardeña, a village within the study area, and Granada, a city about $200 \mathrm{~km}$ away. In Cardeña, a total of 305 people were invited to participate in the survey, and 268 of these filled out the questionnaire ( $87.8 \%$ response rate). In Granada (a city which according to the municipal census for 2016 had 234,758 inhabitants), 480 people were invited to participate in the survey, and 252 questionnaires were filled out (52.5\% response rate). Overall, 520 questionnaires were filled out.
The response rates, especially in the case of Cardeña, were high in comparison with those obtained in previous studies (Arnberger \& Eder 2011; Curado et al. 2013; Grammatikopoulou et al. 2012).

As regards the profile of the respondents, in the case of Cardeña, $60.4 \%$ were men and $39.6 \%$ women, while in Granada $48.1 \%$ were men and $51.9 \%$ women. In both places, the age of the respondents ranged between 16 and 89 years old. 35 of the respondents from Cardeña were livestock farmers; no other job or profession that might influence preferences was identified.

The survey was conducted in a personal, direct way, interviewing the respondents face to face. In Cardeña the interviews took place in the main square of the village, while in Granada they were performed in two university campuses and in one of the main squares in the city centre. Each interview lasted 4 minutes on average.

\subsection{Data Analysis}

A database was created with the results of the 520 questionnaires. In order to analyse the possible influence of certain factors, the data were grouped 
according to the following criteria: familiarity with the landscape (questionnaires obtained in Cardeña or in Granada), gender (men or women) and direct involvement with livestock (the farmers' questionnaires were analysed separately). The preferences expressed by the respondents within each pair of images were expressed as percentages and calculated for the different groups. This allowed us to generate graphs and matrices based on their choices.

\section{Results}

\subsection{General preferences for the different pairs of images}

The results of this study varied greatly from one pair of images to the next (Figure 3). The strongest preference for a scene with animals was in pair " $A$ " (cattle vs. no cattle), for which more than three quarters of the respondents $(76.7 \%)$ chose the scene with cattle. In percentage terms, this was followed by pair "D" (pigs vs. no pigs), for which $71.9 \%$ of the respondents chose the scene with animals. In pair " $E$ " (cattle vs. density and diversity of vegetation) the majority of respondents also preferred the scene with animals. $61.9 \%$ chose the scene with cattle, while $38.1 \%$ preferred the scene with a greater density and diversity of vegetation.

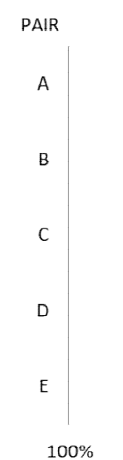

$100 \%$

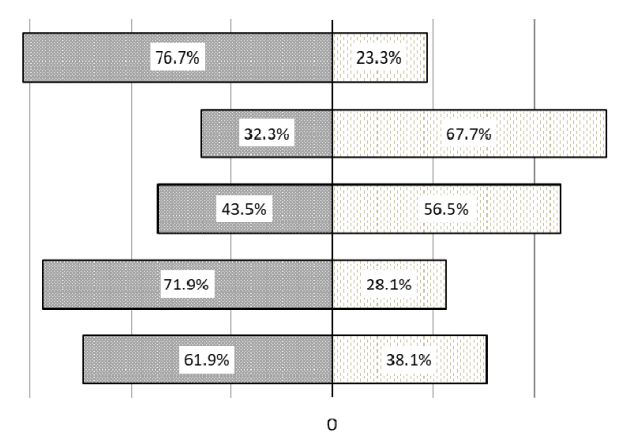

$\square$ Scene with animals
In two of the pairs, a majority of respondents preferred the scene without animals. In pair " $C$ " (cattle vs. traditional farmhouse), $56.5 \%$ of the respondents preferred the scene with the traditional farmhouse, while $43.5 \%$ chose the scene with cattle. The lowest percentage for scenes with animals was in Pair B, in which respondents were asked to choose between a scene with horses and a scene in which water was the striking landscape feature. In this case just $32.3 \%$ of the respondents chose the picture with horses.

\subsection{Familiarity, gender and direct involvement}

When the different groups of population were analysed separately (Cardeña or Granada, men or women, and livestock farmers) significant differences emerged, especially in some pairs of images. The choice matrix in Table 2 shows, for each pair of pictures, the percentage of people from the different groups who chose scenes with animals.

Table 2: Choice matrix. Percentage of respondents that chose scenes with animals for each pair of images.

\begin{tabular}{cccccc}
\hline Pair & $\mathrm{A}$ & $\mathrm{B}$ & $\mathrm{C}$ & $\mathrm{D}$ & $\mathrm{E}$ \\
\hline $\begin{array}{c}\text { Combination } \\
\text { of attributes }\end{array}$ & $\begin{array}{c}\text { Cattle } \\
\text { vs. } \\
\text { No cattle }\end{array}$ & $\begin{array}{c}\text { Horses } \\
\text { vs. } \\
\text { Water }\end{array}$ & $\begin{array}{c}\text { Cattle } \\
\text { vs. } \\
\text { Farmhouse }\end{array}$ & $\begin{array}{c}\text { Pigs } \\
\text { vs. } \\
\text { No pigs }\end{array}$ & $\begin{array}{c}\text { Cattle } \\
\text { vs. } \\
\text { Vegetation }\end{array}$ \\
\hline Total & 76.7 & 32.3 & 43.5 & 71.9 & 61.9 \\
Men & 76.3 & 32.2 & 44.9 & 77.7 & 59.4 \\
Women & 77.2 & 32.5 & 41.8 & 65 & 65 \\
\hline Granada & 84.1 & 28.2 & 42.5 & 61.1 & 72.6 \\
Men & 86 & 26.4 & 41.3 & 71.1 & 68.6 \\
Women & 82.4 & 29.8 & 43.5 & 51.9 & 76.3 \\
Cardeña & 69.8 & 36.2 & 44.4 & 82.1 & 51.9 \\
Men & 69.1 & 36.4 & 47.5 & 82.7 & 52.5 \\
Women & 70.8 & 35.8 & 39.6 & 81.1 & 50.9 \\
\hline Farmers & 93.8 & 59.4 & 59.4 & 93.7 & 71.9 \\
\hline
\end{tabular}

As regards the place where the survey was conducted (familiarity with the landscape), certain differences can be detected in practically all the pairs. In pair " $D$ " (pigs vs. no pigs) for example, the scene with animals was much more popular in Cardeña than in Granada (82.1\% compared to $61.1 \%$ ). A large percentage difference was also observed in pair " $E$ " (cattle vs. density and diversity of vegetation), in which the choice of the scene with animals was 20.7 percentage points higher in Granada than in Cardeña. 
As regards the gender of the respondents, the general results show a considerable difference in pair " $D$ " (pigs vs. no pigs), in which $12.7 \%$ more men chose the scene with animals than women $177.7 \%$ compared to 65\%). If the choices for pair " $D$ " are analysed for Granada and Cardeña separately, the gender difference increases in the case of Granada $(19.2 \%)$, while it is almost irrelevant in the case of Cardeña (1.6\%).

A small difference between men and women could also be found in pair " $E$ " (cattle vs. density and diversity of vegetation), in which $5.6 \%$ more women than men chose the scene with animals. The difference between the genders was again more evident in respondents from Granada (7.7\%). No significant differences between the sexes were observed in the results for the other pairs.

As regards the choices of the livestock farmers, people who are directly involved and knowledgeable about the role of animals in the dehesa, in all the pairs the results showed substantially higher-thanaverage percentages of respondents choosing scenes with animals (Table 2, Figure 4).

\subsection{Inclusion of other landscape attributes}

In two of the pairs of pictures in the image-based questionnaire a scene with animals was compared with a similar scene without animals; however, in

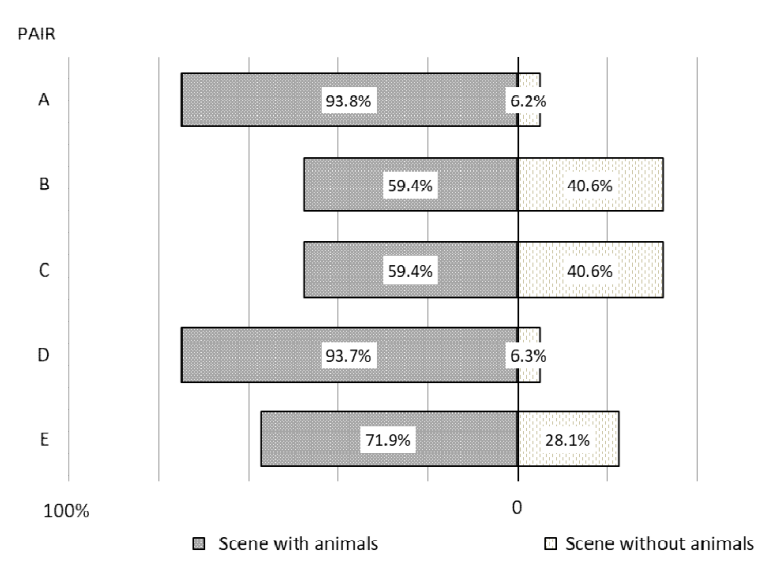

Figure 4: Choices made by livestock farmers of scenes with or without animals for each pair of images. Pair A: cattle vs. no cattle; Pair B: horses vs. water; Pair C: cattle vs. traditional farmhouse; Pair D: pigs vs. no pigs; Pair E: cattle vs. density and diversity of vegetation. the three other pairs, the scenes with animals were compared with scenes showing other landscape attributes (water, a traditional farmhouse and greater density and diversity of vegetation). On the basis of this information, we created a table showing the effect that contrasting other attributes with the presence of animals has on the choices (Table 3).

Table 3: Percentage of respondents choosing scenes with animals per type of pairs: the pairs in which a scene with animals is compared with another similar scene without animals (pairs $A$ and D) are contrasted with the pairs in which scenes with animals are compared with scenes with other kinds of attributes (pairs B, C and E).

\begin{tabular}{ccc}
\hline $\begin{array}{c}\text { Kind of } \\
\text { pairs }\end{array}$ & $\begin{array}{c}\text { Scene with animals } \\
\text { vs. } \\
\text { Scene without animals }\end{array}$ & $\begin{array}{c}\text { Scene with animals } \\
\text { vs. }\end{array}$ \\
\hline Total & 74.3 & Scene with another attribute \\
\hline Men & 77 & 45.9 \\
Women & 71.1 & 45.5 \\
Granada & 72.6 & 46.4 \\
Men & 78.5 & 47.8 \\
Women & 67.2 & 45.5 \\
Cardeña & 75.9 & 49.9 \\
Men & 75.9 & 44.2 \\
\hline Women & 75.9 & 45.5 \\
Farmers & 93.8 & 42.1 \\
\hline
\end{tabular}

Overall, when similar scenes with and without animals were compared, $74.3 \%$ of the respondents chose the scene with animals; however, when these were compared with scenes containing other kinds of attributes, less than half the respondents (45.9\%) preferred the scene with animals. In all cases, the percentage of people choosing scenes with animals fell by approximately 30 percentage points when compared with other kinds of attributes.

Nevertheless, if we look at Table 2 again, we find that in the case of the respondents from Granada, the percentage of people who chose the scene with animals in pair " $D$ " (pigs vs. no pigs) was considerably lower than in pair " $\mathrm{A}$ " (cattle vs. no cattle) $(61.1 \%$ vs. $84.1 \%$ ), even if both pairs of pictures showed similar scenes with and without animals. 


\section{Discussion and Conclusions}

\subsection{Exploring the influence of animals on landscape preferences}

In this study we conducted a survey to evaluate the role that livestock play in landscape preferences. Previous studies using image-based questionnaires to assess landscape preferences used computermanipulated images so as to exclude potentially confounding variables (Arnberger \& Eder 2011). Given that all our pictures were taken on the same day, in the same area and in the same kind of landscape (a dehesa landscape), we decided that computer manipulation was not strictly necessary.

Despite the relatively small number of pictures used in our experiment $(2 \times 5)$, the results confirm that the presence of domestic animals influences landscape preferences. This corroborated the hypothesis of Hull and McCarthy (1988) regarding the scenic impact of animals (both domestic and wild): "The scenic impact of wildlife varies with the amount and type of other landscape features and/or the amount and type of wildlife" (p. 269). Our study revealed a high preference for scenes with livestock.

Law \& Zube (1983) warned about the potential effect that the presence of animals can have on the scenic attraction when research into landscape preferences is carried out using pictures. Various different studies conducted using image-based questionnaires refer to the presence of animals as one of the preferred landscape attributes (Álvarez-lbañez et al. 1999; Grammatikopoulou et al. 2012; Howley et al. 2012; Hull \& McCarthy 1988; Soliva et al. 2010).

In their analysis of the scenic impact of ephemeral landscape attributes, Hull and McCarthy (1988) found that the presence of wildlife was a highly valued attribute. As regards domestic animals, the results obtained by Soliva et al. (2010) in an analysis of the preferences for future landscapes in the Swiss Alps showed relatively high ratings for scenes with grazing cattle, observing certain differences depending on the type of breed. On similar lines, Grammatikopoulou et al. (2012) noticed a greater preference for scenes with grazing animals (cattle and horses) in research on landscape preferences conducted in the south of Finland. The study on public preferences for traditional rural landscapes in Ireland conducted by Howley et al. (2012) is also worthy of note. In this case the presence of horses was once again the most popular attribute.

By contrast, in an image-based study of changes in landscape preferences in environmental education programmes, Benayas et al. (1989) observed a negative response to scenes that contained domestic animals (goats, cows etc.), due to the fact that these species were normally associated with highly anthropized rural landscapes. Given that this research was conducted almost 30 years ago, social changes in recent decades could explain the different attitude towards livestock observed in this investigation as compared to the results of more recent research.

The results of this study reveal the importance of variables such as familiarity with the landscape, gender and above all direct involvement, in the choice of certain scenes with animals.

As regards the choices made in pair "B", the high preference for the scene with water confirms the findings of various previous authors (Howley 2011; Kaltenborn \& Bjerke 2002; Yang \& Kaplan 1990). However, other researchers found that horses are considered a charismatic species (Sharp et al. 2011), and are often preferred to other animals according to different studies (Grammatikopoulou et al. 2012; Howley et al. 2012), while in our survey, the scene with horses was chosen by just one third of the respondents. This shows that although both these landscape attributes have proven popular in previous research, scoring high rates of preference, water is much more popular. When they were directly compared in our study, twice as many respondents preferred the picture with water to the one with horses.

In pair " $\mathrm{C}$ " (cattle vs. traditional farmhouse) there was a high preference for the scene containing a traditional farmhouse. This confirms the results obtained in previous investigations. Arriaza et al. (2004) observed an improvement in the perceived quality of a rural scene when well-preserved traditional features appeared. Grammatikopoulou et al. (2012), in addition to a positive appraisal of the scenes of grazing animals, discovered a strong preference for the renovation of rural buildings. 
The background of the populations surveyed (rural vs. urban) also affected their landscape preferences (Yu 1995). The differences were especially significant in the preferences for pair " $D$ " (pigs vs. similar scene without pigs) in which the percentage of people from Cardeña (rural background) that chose the scene with pigs was much higher than in Granada (urban background). A clear correlation can also be established with the respondents' familiarity with the landscape, as extensive breeding of the Iberian pig is one of the traditional uses of the Spanish dehesa (Lopez-Bote 1998) and is very popular in the study area. The respondents' background and their familiarity with the landscape are therefore important factors in the higher preference for the scene with pigs expressed by people from Cardeña. In this sense, our results corroborate those obtained by Entwistle and Stephenson (2000), who observed significant differences between the types of animal species preferred by a group of schoolchildren in Tanzania compared to those chosen by another group of children surveyed in the United Kingdom.

As Urbanik (2012) points out, pigs have historically had a bad reputation as impure, gluttonous and lazy animals and even today are not considered as kind or brave. Instead they tend to be seen as "food" and do not receive the same treatment and consideration as other livestock species. This could explain why in pairs " $A$ " and " $D$ " (similar scenes with and without animals), fewer people from Granada chose the scene with pigs compared to the scene with cows. Pigs do not always inspire the same affection as cattle, a fact that highlights the different attitudes of the population towards different animal species, as argued by Knight (2008).

The differences in the choices made by men and women, which are especially evident in pair " $D$ " (pigs vs. no pigs) in the particular case of the respondents from Granada, confirm the importance of gender in attitudes towards animals. This trend was observed in the study conducted by Kellert and Berry (1987) on the analysis of attitudes, knowledge and behaviour in relation to wildlife, as well as in the studies conducted by Zinn and Pierce (2002) and by Kaltenborn et al. (2006) on the attitudes of the population towards potentially dangerous wildlife.
The high percentages amongst farmers choosing the scenes with animals could be linked to the results obtained by Gómez-Limón and De Lucío Fernández (1999), who noted in a study of preferences in agrarian landscapes that livestock farmers tended to have particular, clearly distinguishable preferences. In a similar vein, Buijs et al. (2006) underlined the importance of the functional links established with the landscape in connection with landscape perception and preferences. Level of knowledge is another decisive factor; Holloway and Morris (2013) highlight the importance of what they call the "stockman's eye" in the aesthetic consideration of animals, as farmers have a different attitude towards livestock and see them through different eyes, a fact that undoubtedly influences their landscape preferences. The strong preferences amongst farmers for the scenes with livestock confirms the importance of variables such as direct involvement, knowledge and functional links with the landscape in the choice of scenes with animals.

Jacobs (2009) identified the different mechanisms that explain why we like or dislike certain animals, which could be useful for understanding their impact in landscape preferences. Knight (2008) refers to the importance of aesthetics and attitudes toward certain animal species in public perception and support for the conservation of endangered species. Among the most common phobias in western societies are fear of snakes and spiders (Ulrich 1993), although fear of scorpions and large carnivores is also relatively common (Simaika \& Samways 2010). As a consequence, not all animals trigger positive reactions and many species can have a negative influence on landscape preferences. Our study only included large mammals. It is important to take into account that this group of animals (together with birds) are amongst the most popular (Barua 2011; Leader-Williams \& Dublin 2000). Other wildlife groups, especially reptiles and invertebrates, are much poorly rated.

The fact that animals are domestic or wild, that they are free or captive, could likewise influence landscape preferences. Nevertheless, Álvarez-Ibañez et al. (1999) did not observe significant differences in this respect in a study of landscape preferences conducted in Sierra de los Ancares (Spain). These 
authors found a positive appraisal of all the scenes with animals.

In our study we decided to focus exclusively on domestic animals. In this sense, as Evans \& Yarwood (1995) pointed out, livestock breeds play an important role in the creation of local coherences in the landscape. Therefore, the different types of breeds (autochthonous or allochthonous for instance) can influence landscape preferences in different ways, as the results obtained by Soliva et al. (2010) demonstrate.

The type of scene in which animals appear can also be a determining factor. The presence of wildlife in urban areas for instance is not usually well perceived due to possible conflicts with people: damages to gardens, buildings and infrastructures, attacks on domestic animals and humans, associated risks of zoonoses, etc. (Bateman \& Fleming 2012; Duarte et al. 2015; Jenni-Eiermann et al. 2014).

This study has been conducted using a visual imagebased approach; nevertheless, as García Pérez (2002) points out, other landscape components such as sound, smell and movement can also affect preferences in a crucial way, especially when associated with animals (Hull \& McCarthy 1988).

\subsection{Implications for landscape management and planning}

Different authors have referred to animals as an ephemeral attribute of the landscape, whose presence varies greatly with the seasons and the weather (Brassley 1998; Tveit et al. 2006). Lowenthal (2007) argued that "Wind and weather, light and shadow, clouds and sky, seasonal foliage, the disposition of birds, animals and people make each glimpse a new scene, even when seen repeatedly from the same spot" (p. 636).

In spite of its time-space variability and the difficulty that the direct observation of certain animal species in natural environments can sometimes entail, the affection for some of them provides the fundamental motivating energy that inspires society to get involved in conservation (Lorimer 2007). Research in conservation biology has shown the strategic role played by certain charismatic species, known as "flagship" species, such as otters (Syse 2013) in raising public awareness, action and fundraising for conservation (Caro 2010; Hambler \& Canney 2013). In the same way, the analysis of the influence that farm animals have on landscape preferences can also become an important tool for the planning, management and protection of rural landscapes.

In the specific case of the dehesa landscape, farm animals play a crucial role in that the ancient use of these spaces by livestock farmers was one of the fundamental factors that gave rise to this uniquely Iberian rural landscape. Paniza Cabrera (2015) highlighted the intense transformations in the dehesa landscape since the second half of the last century and pointed to the decline of extensive livestock farming as one of the most important factors of change. On similar lines, Díaz Sanz \& Lozano Valencia (2017) claimed that the abandonment of livestock farming was one of the greatest threats to the numerous dehesas on the Iberian Peninsula. In this context, domestic livestock must command a central position in the design of strategies for the future management of these landscapes.

The ELC does not expressly mention the animal factor in the analysis of landscape. However, it highlights the need to incorporate participatory approaches into landscape protection, planning and management processes. Studies of landscape preferences are becoming an essential tool for encouraging public participation in traditional rural landscapes currently undergoing transformation, as they contribute to a better understanding of the aspirations of local people in the current scenario of landscape change. Given that our findings have shown that the presence of livestock has an impact on landscape preferences, it is essential that these animals be taken into account for a better understanding of public aspirations and values attributed to the rural landscape and when it comes to setting landscape quality objectives in line with those established in the ELC.

Our study should be regarded as an explorative study into the relationship between livestock and landscape preferences. Animal geography should pay more attention to the impact of animals on landscape perception and preferences. The methodology applied in this study can also be used 
in the analysis of visual preferences in other types of landscape. In future research, the influence of animals on landscape preferences will have to be evaluated from a touch, smell and sound perspective. It will also be essential to analyse certain specific factors such as animal species (domestic versus wild, small versus large, taxonomic differences, etc.), the number of animals appearing in the scene, the influence of livestock breeds or the different scenic impact of animals depending on the type of landscape in which they appear (urban, rural, etc.).

\section{Acknowledgements}

We would like to thank Program 6A of the Own Research Plan from the University of Granada. The authors are also grateful to the management of the Sierra de Cardeña y Montoro Natural Park for their support during the fieldwork phase.

\section{References}

Adevi, A. A. \& Grahn, P. 2012. Preferences for landscapes: A matter of cultural determinants or innate reflexes that point to our evolutionary background? Landscape Research, 37(1), 27-49. DOI: 10.1080/01426397.2011.576884

Álvarez-lbañez, M.; Otero-Pastor, I. \& SolanaGutiérrez, J. 1999. Valoración y análisis de preferencias sociales de los distintos conjuntos paisajísticos de la RNC de los Ancares (León y Lugo). [Assessment and analysis of social preferences of different scenic sets of the RNC of Ancares (León and Lugo)] In: I. Otero-Pastor (ed.): Paisaje, Teledetección y SIG. Conceptos y Aplicaciones [Landscape, Remote Sensing and GIS. Concepts and Applications] (pp. 81-158). Fundación Conde del Valle Salazar.

Arias-García, J.; Serrano-Montes, J. L. \& GómezZotano, J. 2016. Fauna in Wetland Landscapes: A Perception Approach. Landscape Research, 41(5), 510-523. DOI: 10.1080/01426397.2015.1081160
Arnberger, A. \& Eder, R. 2011. Exploring the heterogeneity of rural landscape preferences: An image-based latent class approach. Landscape Research, 36(1), 19-40. DOI: 10.1080/01426397.2010.536204

Arriaza, M.; Cañas-Ortega, J. F.; Cañas-Madueño, J. A. \& Ruiz-Aviles, P. 2004. Assessing the visual quality of rural landscapes. Landscape and Urban Planning, 69, 115-125. DOI: 10.1016/j. landurbplan.2003.10.029

Barroso, F. L.; Pinto-Correia, T.; Ramos, I. L.; Surová, D. \&Menezes, H. 2012. Dealing with landscape fuzziness in user preference studies: Photo-based questionnaires in the Mediterranean context. Landscape and Urban Planning, 104(3), 329-342. DOI: 10.1016/j.landurbplan.2011.11.005

Barua, M. 2011. Mobilizing metaphors: the popular use of keystone, flagship and umbrella species concepts. Biodiversity and Conservation, 20, 1427-1440. DOI: 10.1007/s10531-011-0035-y

Bastian, O.; Krönert, R. \& Lipský, Z. 2006. Landscape diagnosis on different space and time scales $-\mathrm{a}$ challenge for landscape planning. Landscape Ecology, 21, 359-374. DOI: 10.1007/s10980-0055224-1

Bateman, P. W. \& Fleming, P. A. 2012. Big city life: carnivores in urban environments. Journal of Zoology, 28, 1-23. DOI: 10.1111/j.14697998.2011.00887.x

Benayas, J.; Ruiz, J. P.; De Lucio, J. V. \& Barrios, J. C. 1989. Evaluación de los cambios de preferencias paisajísticas en programas de educación ambiental. Arbor, 518-519, 235-261.

Benayas, J. 1992. Paisaje y Educación Ambiental. Evaluación de cambios de actitudes hacia el entorno. Monografías de la Secretaría de Estado para las Políticas del Agua y el Medio Ambiente. Madrid: MOPT.

Brassley, P. 1998. On the unrecognized significance of the ephemeral landscape. Landscape Research, 23(2), 119-132. DOI: $10.1080 / 01426399808706531$ 
Buijs, A. E.; Pedroli, B. \& Luginbuhl, Y. 2006. From hiking through farmland to farming in a leisure landscape: Changing social perceptions of the European landscape. Landscape Ecology, 21, 375389. DOI: 10.1007/s10980-005-5223-2

Buller, H. 2013. Animal geographies I. Progress in Human Geography, 38(2), 308-318. DOI: 10.1177\%2F0309132513479295

Buller, H. 2015. Animal geographies II: methods. Progress in Human Geography, 39(3), 374-384. DOI: $10.1177 \% 2 F 0309132514527401$

Buller, H. 2016. Animal geographies III: ethics. Progress in Human Geography, 40(3), 422-430. DOI: 10.1177\%2F0309132515580489

Carbonero, M. D. \& Fernández-Rebollo, P. 2014. Dehesas de encinas. Influencia de la meteorología en la producción de bellotas [Holm oak savannas. Influence of weather on acorn production]. Ecosistemas, 23(2), 55-63. DOI: 10.7818/ ECOS.2014.23-2.08

Caro, T. 2010. Conservation by proxy: indicator, umbrella, keystone, flagship, and other surrogate species. Island Press, Washington.

Curado, G.; Manzano-Arrondo, V.; Figueroa, E. \& Castillo, J. M. 2013. Public perceptions and uses of natural and restored salt marshes. Landscape Research, 39 (6), 668-679. DOI: 10.1080/01426397.2013.772960

Council of Europe 2000. The European Landscape Convention. (Available at: http://conventions. coe.int/Treaty/en/Treaties/Html/176.htm) (Date 05.06.2018)

Díaz Sanz, M. C. \& Lozano Valencia, P. J. 2017. Los paisajes de dehesa de la provincia de Ciudad Real. Caracterización y valoración biogeográfica a través de la metodología LANBIOEVA [The landscapes of pasture in the province of Ciudad Real. Characterization and biogeographic evaluation]. Cuadernos Geográficos 56(3), 187-206.
Duarte, J.; Farfán, M. A.; Fa, J. E. \& Vargas, J. M. 2015. Deer populations inhabiting urban areas in the south of Spain: habitat and conflicts. European Journal of Wildlife Research, 61 (3), 365-377. DOI: 10.1007/s10344-015-0902-z

Entwistle, A. C. \& Stephenson, P. J. 2000. Small mammals and the conservation agenda. In: A. Entwistle \& N. Dunstone (eds.): Priorities for the Conservation of Mammalian Diversity. Has the Panda had its Day? (pp. 119-139). Cambridge. University Press, Cambridge, UK.

Evans, N. \& Yarwood, R. 1995. Livestock and landscape. Landscape Research, 20, 141-146. DOI: 10.1080/01426399508706468

Fernández, N. 2011. Landscapes for the Iberian Lynx: Disentangling effects on habitat suitability in Sierra Morena. In: J. M. Quero Fernández de Molina (ed.): Sierra de Cardeña y Montoro Natural Park: research, projects and studies (pp. 291-299). Córdoba: Servicio de Publicaciones (Universidad de Córdoba), Fundación CajaSur.

Folmer, A.; Haartsen, T. \& Huigen, P. P. 2013. The role of wildlife in emotional attachment to a nature-based tourism destination. Journal of Ecotourism, 12(3), 131-145. DOI: 10.1080/14724049.2013.864297

García Pérez, J. D. 2002. Ascertaining landscape perceptions and preferences with pairwise photographs: Planning rural tourism in Extremadura, Spain. Landscape Research, 27(3), 297-308. DOI: 10.1080/01426390220149539

Garzón-García, R. 2005. Algunas implicaciones territoriales de la intervención administrativa en la gestión del Parque Natural Sierra de Cardeña y Montoro (Córdoba) [Some territorial implications of administrative involvement in the management of the Sierra de Cardena y Montoro Natural Park (Córdoba)]. Geographicalia, 46, 51-75.

Gómez-Limón, J. \& De Lucío Fernández, J. V. 1999. Changes in use and landscape preferences on the agricultural livestock landscapes of central Iberian Peninsula (Madrid, Spain). Landscape 
and Urban Planning, 44, 165-175. DOI: 10.1016/ S0169-2046(99)00020-1

Gorman, R. 2017. Therapeutic landscapes and nonhuman animals: the roles and contested positions of animals within care farming assemblages. Social \& Cultural Geography, 18 (3), 315-335. DOI: $10.1080 / 14649365.2016 .1180424$

Grammatikopoulou, I.; Pouta, E.; Salmiovirta, M. \& Soini, K. 2012. Heterogeneous preferences for agricultural landscape improvements in southern Finland. Landscape and Urban Planning, 107, 181191. DOI: 10.1016/j.landurbplan.2012.06.001

Hagerhall, C. M. 2000. Clustering predictors of landscape preference in the traditional Swedish cultural landscape: prospect-refuge, mystery, age and management. Journal of Environmental Psychology, 20(1), 83-90. DOI: 10.1006/ jevp.1999.0150

Hambler, C. \& Canney, S. M. 2013. Conservation. New York, Cambridge University Press.

Holloway, L. \& Morris, C. 2013. Viewing animal bodies: truths, practical aesthetics and ethical considerability in UK livestock breeding. Social \& Cultural Geography, 15(1), 1-22. DOI: 10.1080/14649365.2013.851264

Hovorka, A. J. 2017. Animal geographies I: Globalizing and decolonizing. Progress in Human Geography, Vol. 41, 3, pp. 382-394.

Hovorka, A. J. 2018a. Animal geographies II: Hybridizing. Progress in human geography, 42(3), pp.453-462.DOI:10.1177\%2F0309132516646291

Hovorka, A. J. 2018b. Animal geographies III: Species relations of power. Progress in human geography, Progress report, pp. 1-9. DOI: 10.1177/0309132518775837
Howley, P. 2011. Landscape aesthetics: Assessing the general publics' preferences towards rural landscapes. Ecological Economics, 72, 161-169. DOI: 10.1016/j.ecolecon.2011.09.026

Howley, P.; Donoghue, C. O. \& Hynes, S. 2012. Exploring public preferences for traditional farming landscapes. Landscape and Urban Planning, 104, 66-74. DOI: 10.1016/j. landurbplan.2011.09.006

Hull, R. B. \& McCarthy, M. M. 1988. Change in the landscape. Landscape and Urban Planning, 15(3), 265-278. DOI: 10.1016/0169-2046(88)90050-3

International Federation of Landscape Architects. 2013. Latin American Landscape Initiative. http://www.csla-aapc.ca/sites/csla-aapc.ca/ files/IFLA/120910\%20LALI_EN--.pdf (Date: 10.06.2018)

Jacobs, M. H. 2009. Why do we like or dislike animals? Human Dimensions of Wildlife, 14(1), 1-11. DOI: 10.1080/10871200802545765

Jenni-Eiermann, S.; Heynen, D. \& Schaub, M. 2014. Effect of an ultrasonic device on the behaviour and the stress hormone corticosterone in feral pigeons. Journal of pest science, 87(2), 315-322. DOI: 10.1007/s10340-014-0553-y

Jones, O. 2013. "Who Milks the Cows at Maesgwyn?" The animality of UK rural landscapes in affective registers. Landscape Research, 38(4), 421-442. DOI: $10.1080 / 01426397.2013 .784246$

Jorgensen, A. 2011. Beyond the view: Future directions in landscape aesthetics research. Landscape and Urban Planning, 100, 353-355. DOI: 10.1016/j.landurbplan.2011.02.023

Kaltenborn, B. P., \& Bjerke, T. 2002. Associations between environmental value orientations and landscape preferences. Landscape and Urban Planning, 59, 1-11. DOI: 10.1016/S01692046(01)00243-2 
Kaltenborn, B. P.; Bjerke, T. \& Nyahongo, J. 2006. Living with problem animals-self-reported fear of potentially dangerous species in the Serengeti Region, Tanzania. Human Dimensions of Wildlife: An International Journal, 11(6), 397-409. DOI: $10.1080 / 10871200600984323$

Kaplan, R. \& Kaplan, S. 1989. The experience of nature: A psychological perspective. New York, Cambridge University Press.

Kellert, S. R. \& Berry, J. K. 1987. Attitudes, knowledge, and behaviors toward wildlife as affected by gender. Wildlife Society Bulletin, 15, 363-371.

Knight, A. J. 2008. Bats, snakes and spiders, Oh my! How aesthetic and negativistic attitudes, and other concepts predict support for species protection. Journal of Environmental Psychology, 28, 94-103. DOI: 10.1016/j.jenvp.2007.10.001

Lange, E. \& Bishop, I. D. 2005. Communication, perception and visualization. In: E. Lange \& I. D. Bishop (eds.): Visualization in landscape and environmental planning: Technology and applications (pp. 3-23). New York: Taylor and Francis.

Law, C. S. \& Zube, E. H. 1983. Effects of photographic composition on landscape perception. Landscape Research, 8(1), 22-23. DOI: 10.1080/01426398308706052

Leader-Williams, N. \& Dublin, H. 2000. Charismatic megafauna as 'flagship species'. In: A. Entwistle \& N. Dunstone (eds.): Priorities for the Conservation of Mammalian Diversity: Has the Panda Had its Day? (pp. 53-81). Cambridge University Press, Cambridge.

Lopez-Bote, C. J. 1998. Sustained utilization of the Iberian pig breed. Meat Science, 49, 17-27. DOI: 10.1016/S0309-1740(98)90036-5

Lorimer, J. 2007. Nonhuman charisma. Environment and Planning D: Society and Space, 25, 911-932. DOI: $10.1068 \% 2 \mathrm{Fd} 71 \mathrm{j}$
Lorimer, J. \& Srinivasan, K. 2013. Animal geographies. In: N. C. Johnson, R. H. Schein \& J. Winders (eds.): The Wiley-Blackwell Companion to Cultural Geography (pp. 332-342). Wiley-Blackwell, Oxford.

Lowenthal, D. 2007. Living with and looking at landscape. Landscape Research, 32(5), 635-656. DOI: 10.1080/01426390701552761

Mealey, L. \& Theis, P. 1995. The relationship between mood and preferences among natural landscapes: An evolutionary perspective. Ethology and Sociobiology, 16(3), 247-256. DOI: 10.1016/01623095(95)00035-J

Múgica, M. \& De Lucio, J. V. 1996. The role of onsite experience on landscape preferences. A case study at Doñana National Park (Spain). Journal of Environmental Management, 47, 229-239. DOI: 10.1006/jema.1996.0049

Ode, A.; Hagerhall, C. M. \& Sang, N. 2010. Analysing Visual Landscape Complexity: Theory and Application. Landscape Research, 35(1), 111-131. DOI: 10.1080/01426390903414935

Paniza Cabrera, A. 2015. The Landscape of the Dehesa in the Sierra Morena of Jaén (Spain)-the Transition from Traditional to New Land Uses. Landscape Online, 43, 1-15. DOI 10.3097/ LO.201543.

Peltola, T.; Heikkilä, J. \& Vepsäläinen, M. 2013. Exploring landscape in-the-making: a case study on the constitutive role of animals in societynature interactions. Landscape Research, 38(4), 461-475. DOI: 10.1080/01426397.2013.773298

Pietzsch, D.; Ochsner, S.; Mantilla-Contreras, J. \& Hampicke, U. 2013. Low-intensity husbandry as a cost-efficient way to preserve dry grasslands. Landscape Research, 38(4), 523-539. DOI: 10.1080/01426397.2012.741223

Quero Fernández de Molina, J. M. 2007. Parque Natural Sierra de Cardeña y Montoro, 1989-2005 [Sierra de Cardeña y Montoro Natural Park, 1989- 
2005]. Servicio de Publicaciones de la Universidad de Córdoba, Universidad de Córdoba. Consejería de Medio Ambiente, Junta de Andalucía.

Roe, M. 2013. Animals and landscape. Landscape Research, 38(4), 401-403. DOI: 10.1080/01426397.2013.829971

Sánchez-Almendro, A. J.; Quijada-Muñoz, J.; MurciaSánchez, E. \& Muñoz-Álvarez, J. M. 2011. Mapping and evaluation of vegetation in the Sierra de Cardeña y Montoro Natural Park. In: J. M. Quero Fernández de Molina (ed.): Sierra de Cardeña y Montoro Natural Park: research, projects and studies (pp. 85-103). Córdoba: Servicio de Publicaciones (Universidad de Córdoba), Fundación CajaSur.

Serrano-Montes, J. L. \& Gómez-Zotano, J. 2017. Methodological proposal for the inclusion of fauna in landscape studies. The example of Casasola beach, Malaga (Spain). Boletín de la Asociación de Geógrafos Españoles, 73, pp. 469472. DOI: 10.21138/bage.2409

Serrano Montes, J. L. 2017. Fauna in landscape studies: Conceptual approaches, a methodological proposal and practical application at three spatial scales. PhD Thesis. University of Granada.

Sellick, J. \& Yarwood, R. 2013. Placing livestock in landscape studies: pastures new or out to graze? Landscape Research, 38(4), 404-420. DOI: 10.1080/01426397.2012.730611

Sevenant, M. \& Antrop, M. 2010. The use of latent classes to identify individual differences in the importance of landscape dimensions for aesthetic preference. Land Use Policy, 27, 827-842. DOI: 10.1016/j.landusepol.2009.11.002

Sharp, R. L.; Larson, L. R. \& Green, G. T. 2011. Factors influencing public preferences for invasive alien species management. Biological Conservation, 144, 2097-2104. DOI: 10.1016/j. biocon.2011.04.032
Simaika, J. P. \& Samways, M. J. 2010. Biophilia as a Universal Ethic for Conserving Biodiversity. Conservation Biology, 24(3), 903-906. DOI: 10.1111/j.1523-1739.2010.01485.x

Soliva, R.;Bolliger,J.\&Hunziker, M. 2010. Differences in preferences towards potential future landscapes in the Swiss Alps. Landscape Research, 35(6), 671696. DOI: 10.1080/01426397.2010.519436

Stamps, A. E., III. 1990. Use of photographs to simulate environments: A meta-analysis. Perceptual and Motor Skills, 71, 907-913. DOI: 10.2466\%2Fpms.1990.71.3.907

Stewart, T. R.; Middleton, P.; Downton, M. \& Ely, D. 1984. Judgments of photographs vs. field observations in studies of perception and judgment of the visual environment. Journal of Environmental Psychology, 4(4), 283-302. DOI: $10.1016 / \mathrm{S} 0272-4944(84) 80001-8$

Sullivan, W. C. 1994. Perceptions of the ruralurban fringe: citizen preferences for natural and developed settings. Landscape and Urban Planning, 29, 81-101. DOI: 10.1016/01692046(94)90020-5

Swanwick, C. \& Land Use Consultants 2002. Landscape character assessment - guidance for England and Scotland CAX 84. Countryside Agency, Cheltenham and Scottish Natural Heritage, Edinburgh.

Syse, K. V. L. 2013. Otters as symbols in the British environmental discourse, Landscape Research, 38(4), 540-552. DOI: 10.1080/01426397.2013.784244

Tveit, M. S. 2009. Indicators of visual scale as predictors of landscape preference; a comparison between groups. Journal of Environmental Management, 90(9), 2882-2888. DOI: 10.1016/j. jenvman.2007.12.021 
Tveit, M.; Ode A. \& Fry, G. 2006. Key concepts in a framework for analysing visual landscape character. Landscape Research, 31(3), 229-255. DOI: 10.1080/01426390600783269

Ulrich, R. S. 1993. Biophilia, biophobia, and natural landscapes. In: S. R. Kellert \& E. O. Wilson (eds.): The biophilia hypothesis, (pp. 73-138). Island Press.

Urbanik, J. 2012. Placing animals: An introduction to the geography of human-animal relations. Rowman \& Littlefield.

Van den Berg, A. E. \& Koole, S. L. 2006. New wilderness in the Netherlands: An investigation of visual preferences for nature development plans. Landscape and Urban Planning, 78, 362-372. DOI: 10.1016/j.landurbplan.2005.11.006

Wolch, J. 2002. Anima Urbis. Progress in human geography, 26(6), 721-742. DOI: 10.1191\%2F0309132502ph400oa

Wolch, J., Emel, J. \& Wilbert, C. 2003. Reanimating cultural geography. In: K. Anderson, M.Domosh, S.Pile \& N. Thrift (eds.): Handbook of cultural geography. (pp. 184-206). SAGE Publications Ltd.

Yang, B. \& Kaplan R. 1990. The perception of landscape style: A cross-cultural comparison. Landscape and Urban Planning, 19, 251-162. DOI: 10.1016/0169-2046(90)90024-V

Yu, K. 1995. Cultural variations in landscape preference: comparisons among Chinese subgroups and Western design experts. Landscape and Urban Planning, 32(2), 107-126. DOI: 10.1016/0169-2046(94)00188-9

Zinn, H. C. \& Pierce, C. L. 2002. Values, gender, and concern about potentially dangerous wildlife. Environment and Behavior, 34(2), 239-256. DOI: 10.1177\%2F0013916502034002005
Zonneveld, I. S. 2005. The land unit as a black box: a Pandora`s box?. In: J. A. Wiens \& M. R. Moss (eds.): Issues and Perspectives in Landscape Ecology (pp. 331-345). Cambridge University Press. 